\title{
Growth Parameters and Yield of Maize Varieties (Zea mays L.) in Tribal Hills Area of Pali District, Rajasthan, India
}

\author{
M.L. Meena ${ }^{1^{*}}$ and Aishwarya Dudi ${ }^{2}$ \\ ${ }^{1}$ SMS (Agricultural Extension), ICAR-CAZRI, Krishi Vigyan Kendra, Pali-Marwar \\ (Rajasthan) 306401, India \\ ${ }^{2}$ SMS (Home Science), ICAR-CAZRI, Krishi Vigyan Kendra, Pali-Marwar \\ (Rajasthan) 306401, India \\ *Corresponding author
}

A B S T R A C T

Maize is the most important world's leading cereals crop which can be grown in diverse seasons, ecological and uses and known as queen of cereal due to unparallel productivity among cereal crops. Front line demonstrations (FLDs) on maize were laid down at 180 farmers' fields to demonstrate production potential and economic benefits of improved production technologies comprising high yielding varieties namely PEHM-2, PM-3, PM-5, PSM 2 and PM 4 in Pali district of arid zone of Rajasthan state during Kharif seasons from

\section{Keywords}

Adoption,

Knowledge,

Constraints, FLD,

Varieties and maize

Article Info

Accepted:

20 March 2018

Available Online:

10 April 2018
2011 to 2017 in rainfed farming situation. The improved production technologies recorded an additional yield ranging from 3.10 to $9.9 \mathrm{q} / \mathrm{ha}$ with a mean of $6.6 \mathrm{q} / \mathrm{ha}$. The per cent increase yield under improved production technologies ranged from 24.4 to 52.1 (PM-3), 29.6 to 57.1 (PM-5), 16.4 to 36.4 (PEHM-2), 41.8 to 58.4 (PM-4) and 29.6 (PSM-2) in respective years. The average extension gap, technology gap and technology index were $6.6 \mathrm{q} / \mathrm{ha}, 13.4 \mathrm{q} / \mathrm{ha}$ and 36.9 per cent, respectively in different varieties of maize. The improved production technologies gave higher benefit cost ratio ranging from 2.7 to 4.8 with a mean of 3.3 compared to local checks (2.0) being grown by farmers under locality. From the result of the findings that the maximum number of the respondents had medium level of knowledge and extent of adoption regarding recommended maize production technology. The study reported lack of suitable HYV as major constraints by beneficiaries is rank first followed by low technical knowledge. The productivity of maize per unit area could be increased by adopting feasible scientific and sustainable management practices with a suitable variety. Considering the above facts, frontline demonstrations were carried out in a systematic and scientific manner on farmer's field to show the worth of a new variety and convincing farming community about potentialities of improved production management technologies of maize for further adoption by the farming community.

\section{Introduction}

Maize (Zea mays L.) is the most important world's leading cereal crop which can be grown in diverse seasons, ecologies and uses and known as queen of cereal due to unparallel productivity among cereal crops. Globally, it is cultivated on more than $160 \mathrm{~m}$ ha area across 166 countries having wider diversity of soil, climate, biodiversity and 
management practices. In India, maize occupies third position both in area and production followed by rice and wheat (Anonymous, 2017) According to latest data (2016-17), it is being cultivated on $8.6 \mathrm{~m}$ ha with 80 per cent area during kharif season. The current maize production is 21.7 million tones with an average productivity of 24.35 $\mathrm{q} / \mathrm{ha}$. The productivity of India is just half than the world productivity. In Rajasthan it is grown on $0.97 \mathrm{~m}$ ha area with production 1.84 $\mathrm{m}$ tones and productivity of $1888 \mathrm{~kg} / \mathrm{ha}$ (Anonymous, 2016-17). During recent years, Pali district of Rajasthan has emerged as the leading one in maize production in the state.

The productivity of maize in the district is very low as compared to average national productivity $(24.35 \mathrm{q} / \mathrm{ha})$. Lack of suitable high yielding variety as well as poor knowledge about production practices are ascribed as main reasons for low productivity of maize in the district. The productivity of maize per unit area could be increased by adopting recommended scientific and sustainable management production practices using suitable high yielding varieties namely PEHM-2, PM-3, PM-5, PSM 2 and PM 4 (Das et al., 2007; Dhaka, 2010; Ranawat et al., 2011).

Frontline demonstration is the new concept of field demonstration evolved by the Indian Council of Agriculture Research (ICAR) with main objective to demonstrate newly released crop production and protection technologies and its management practices in the farmers' fields under different agro-climatic regions of the country under different farming situations. While demonstrating the technologies in the farmer's fields, the scientists are required to study the factors contributing higher crop production, field constraints of production and thereby generate production data and feedback information. Taking into account the above considerations, frontline demonstrations
(FLDs) were carried out in a systematic manner on farmer's field to show the worth of a new variety and convincing farmers to adopt improved production management practices of maize for enhancing productivity of maize.

\section{Materials and Methods}

The study was conducted in tribal farmers' fields to demonstrate production potential and economic benefits of improved technologies in Pali district tribal hill area of Rajasthan state during Kharif seasons from 2011 to 2017 in rainfed farming situation. To popularize the improved maize production practices, constrains in maize production were identified though participatory approach. Preferential ranking technique was utilized to identify the constraints faced by the respondent farmers in maize production. Farmers were also asked to rank the constraints they perceive as limiting production factor for maize cultivation in order of preference. Based on top rank farmers problems identified, front line demonstrations were planned and conducted at the farmer's fields under ICAR and integrated scheme of oilseeds, pulses, oilpalm and maize (ISOPOM). In all, 472 full package frontline demonstrations were conducted to convince them about potentialities of improved varieties of maize viz., PEHM-2, PM-3, PM-5, PSM 2 and PM 4 during Kharif seasons from 2011 to 2017 under rainfed farming condition, in light to medium soils with low to medium fertility status under chickpea-maize cropping systems.

Each demonstration was conducted in an area of 0.4 ha and adjacent to the farmer's fields in which the crop was cultivated with farmer's practice/ local variety. The package of practices included were improved varieties, seed treatment, maintenance of optimum plant stand, recommended fertilizers dose, plant protection measures especially grass hopper management. The spacing followed was at 
$0.60 \mathrm{~m} \times 0.25 \mathrm{~m}$ sown between third week of June to first week of July during the five years with the seed rate of $25 \mathrm{~kg} / \mathrm{ha}$. All the participating farmers were trained on all aspects of maize production management. To study the impact of front line demonstrations, out of 661 participating farmers, a total of 160 farmers were selected as respondent through proportionate sampling. Production and economic data for FLDs and local practices were collected and analyzed. The Extension gap, technology gap and technology index were calculated using the formula as suggested by Samui et al., (2000).

Extension gap $\left(\mathrm{qha}^{-1}\right)=$ Demonstration yield $\left(\mathrm{qha}^{-1}\right)$-Yield of local check $\left(\mathrm{qha}^{-1}\right)$

Technology gap (qha-1) = Potential yield $\left(\mathrm{qha}^{-1}\right)-$ Demonstration yield $\left(\mathrm{qha}^{-1}\right)$.

$\left.\frac{\begin{array}{l}\text { Technology index } \\ \text { Potential yied-Demonstration yield }\end{array}}{\text { Potential yield }} \times 1 \%\right)=$

Knowledge level of the farmers about improved production practices of maize before frontline demonstration implementation and after implementation was measured and compared by applying paired t-test at 5 per cent level of significance. Further, the satisfaction level of respondent farmers about extension services provided was also measured based on various dimensions like training of participating farmers, timeliness of services, supply of inputs, solving field problems and advisory services rendered, fairness of scientists, performance of variety demonstrated and overall impact of FLDs. The selected respondents were interviewed personally with the help of a pre-tested and well-structured interview schedule. Client Satisfaction Index was calculated as developed by Kumaran and Vijayaragavan (2005). The individual obtained scores were calculated by the formula as:
Client Satisfaction
The individual obtained score
Maximum score possible

The data thus collected were tabulated and statistically analyzed to interpret the FLDs results.

\section{Results and Discussion}

\section{Constraints in maize production}

Farmer's maize production problems were documented in this study. Preferential ranking technique was utilized to identify the constraints faced by the respondent farmers in maize production. The ranking given by the different farmers are given in Table 1. A perusal of table indicates that lack of suitable high yielding variety (HYV) (83.9\%) was given the top most rank followed by low technical knowledge $(80.3 \%)$, grass hopper infestation $(76.7 \%)$, vagaries of weather $(69.4 \%)$. Based on the ranks given by the respondent farmers for the different constraints revealed that lack of suitable HYV, low technical knowledge, grass hopper infestation are the major constraints to maize production and followed by wild animals. Other constraints such low or erratic rainfall, stem borer infestation, stem rot, weed infestation, water lodging, marketing and postharvest management were found to reduce maize production. Among all the constraints, low soil fertility got least concerns. Other studies (Hassan et al., 1998; Ouma et al., 2002; Joshi et al., 2005; Dhaka et al., 2010; Ranawat et al., 2011; Dhruw et al., 2012; Sreelakshmi et al., 2012) have reported similar problems in maize production.

\section{Performance of FLD}

A comparison of productivity levels between demonstrated varieties and local checks is shown in Table 4. During the period under 
study, it was observed that the productivity of maize in Pali district under improved production technologies ranged between 15.3 to $28.1 \mathrm{q} / \mathrm{ha}$ with a mean yield of $22.9 \mathrm{q} / \mathrm{ha}$. The productivity under improved technologies varied from 17.8 to $25.9,15.3$ to $22.2,20.3$ to $24.5,24.3$ to 26.8 and $28.1 \mathrm{q} / \mathrm{ha}$ for the varieties PM-3, PEHM-2, PM-5 and PM 4, respectively as against the yield range between 11.7 to 20.4 with a mean of $16.2 \mathrm{q} /$ ha under farmers local practices and varieties during study period. The additional yield of different varieties under improved production technologies over local practices ranged from 3.1 to $9.4 \mathrm{q} / \mathrm{ha}$ with a mean of $6.6 \mathrm{q} / \mathrm{ha}$ in comparison to local practice and varieties. The per cent increase yield under improved production technologies ranged from 26.9 to 43.5 (PM-3), 29.6 to 57.1 (PM-5), 16.4 to 36.4 (PEHM-2), 41.8 to 58.4 (PM 4) and 52.4 (PSM 2) in respective years. This increased grain yield with improved production technologies was mainly because of high potential yielding varieties.

The variation in the productivity was also caused unusual delay in sowing in some of the farmer's fields. In fields where delayed sowing was done because of prolonged dry spell in the month of July and delay onset of monsoon rains, the crop growth was restricted. The late sowing crop was subjected to relatively less time span available for plant growth and development. Similar yield enhancement in different crops in front line demonstration has amply been documented by Haque (2000), Tiwari and Saxena (2001), Tiwari et al., (2003), Nazrul Islam et al., (2004), Hiremath et al., (2007), Mishra et al., (2009), Tomar et al., (2009), Dhaka et al., (2010), Kumar et al., (2010) and Sreelakshmi et al., (2012). From these results it is evident that performance of improved varieties was found better than the local check under local conditions. Farmers were motivated by results of agro technologies applied in the FLDs trials and it is expected that they would adopt these technologies in the coming years also. Yield of the front demonstration trials and potential yield of the different varieties of crop was compared to estimate the yield gaps which were further categorized into technology index. The technology gap shows the gap in the demonstration yield over potential yield and it was $13.4 \mathrm{q} / \mathrm{ha}$. The observed technology gap may be attributed to dissimilarities in soil fertility, salinity and erratic rainfall and other vagaries of weather conditions in the area. Hence, to narrow down the gap between the yields of different varieties, location specific recommendation appears to be necessary. Technology index shows the feasibility of the variety at the farmer's field. The lower the value of technology index more is the feasibility. Table 4 revealed that the technology index value was 36.9 .

The findings of the present study are in line with the findings of Sawardekar et al., (2003), Hiremath and Nagaraju (2009) and Dhaka et al., (2010). The economic feasibility of improved technologies over traditional farmer's practices was calculated depending on the prevailing prices of inputs and output costs (Table 5). It was found that cost of production of maize under improved technologies varied from Rs.8550 to Rs. $12500 \mathrm{ha}^{-1}$ in case of PM-3, Rs. 8790 to Rs. $9220 \mathrm{ha}^{-1}$ for PM-5, Rs. 8660 to Rs. 10900 $\mathrm{ha}^{-1}$ for PEHM-2, Rs. 8180 to Rs. $12300 \mathrm{ha}^{-1}$ for PM 4 and Rs.9700 ha ${ }^{-1}$ in case of PSM 2 with an average of Rs. $9744.4 \mathrm{ha}^{-1}$ with an average of Rs. 9372.5 ha $^{-1}$ in local practice. The additional cost incurred in the improved technologies was mainly due to more costs involved in the cost of improved seed only. Front line demonstrations recorded higher mean gross returns (Rs. $32466.7 \mathrm{ha}^{-1}$ ) and mean net return (Rs.22722.2 ha-1) with higher benefit ratio (3.3) under improved technologies of different improved varieties of maize as compared to local checks. 
Table.1 Ranking given by farmers for different constraints $(\mathrm{N}=160)$

\begin{tabular}{|c|c|c|c|}
\hline S. No. & Constraints & Percentage & Ranks \\
\hline 1 & Lack of suitable high yielding variety & 83.9 & I \\
\hline 2 & Stem rot diseases & 33.8 & VII \\
\hline 3 & Stem borer infestation & 45.3 & VI \\
\hline 4 & Low soil fertility & 27.2 & $\mathrm{X}$ \\
\hline 5 & Low technical knowledge & 80.3 & II \\
\hline 6 & Wild animals & 52.6 & V \\
\hline 7 & $\begin{array}{l}\text { Vagaries of weather (Delay onset of monsoon, early } \\
\text { withdrawn of monsoon and mid season drought) }\end{array}$ & 69.4 & IV \\
\hline 8 & Weed infestation & 29.3 & VIII \\
\hline 9 & Grass hopper infestations & 76.7 & III \\
\hline 10 & Water lodging & 30.9 & IX \\
\hline 11 & Marketing & 26.5 & XI \\
\hline 12 & Post harvest management & 23.7 & XII \\
\hline
\end{tabular}

Table. 2 Compression between knowledge levels of the respondents farmers about improved farming practices of maize $(\mathrm{N}=160)$

\begin{tabular}{|c|c|c|c|}
\hline \multicolumn{3}{|c|}{ Mean score } & \multirow{2}{*}{$\begin{array}{l}\text { Calculated } \\
\text { "t" value }\end{array}$} \\
\hline $\begin{array}{l}\text { Before } \\
\text { implementation }\end{array}$ & $\begin{array}{ll}\text { After } & \text { FLD } \\
\text { implementation } & \end{array}$ & Mean difference & \\
\hline 33.7 & 67.8 & 34.1 & $7.98 *$ \\
\hline
\end{tabular}

*Significant at $5 \%$ probability level; FLD= Front Line Demonstration

Table.3 Extent of farmers satisfaction of extension services rendered $(\mathrm{N}=160)$

\begin{tabular}{|c|c|c|}
\hline Satisfaction level & Number & Percent \\
\hline Low & 23 & 14.8 \\
\hline Medium & 105 & 65.6 \\
\hline High & 32 & 20.0 \\
\hline
\end{tabular}


Table.4 Yield of maize as influenced by improved production technologies and high yielding varieties over local practices in farmer's fields (2009-2015)

\begin{tabular}{|c|c|c|c|c|c|c|c|c|c|c|}
\hline \multirow[t]{2}{*}{ Year } & \multirow[t]{2}{*}{ Variety } & \multirow{2}{*}{$\begin{array}{l}\text { Area } \\
\text { (ha) }\end{array}$} & \multirow{2}{*}{$\begin{array}{l}\text { No. of } \\
\text { Demo. }\end{array}$} & \multicolumn{2}{|c|}{ Yield (q/ha) } & \multirow{2}{*}{$\begin{array}{lr}\text { Add. } & \text { Yield } \\
\text { over } & \text { local } \\
\text { check }(q / h a)\end{array}$} & \multirow{2}{*}{$\begin{array}{lr}\% & \text { increase } \\
\text { over } & \text { local } \\
\text { check } & \\
\end{array}$} & \multirow{2}{*}{$\begin{array}{l}\text { EG } \\
(\mathbf{q} / \mathbf{h a})\end{array}$} & \multirow{2}{*}{$\begin{array}{l}\text { TG } \\
\text { q/ha) }\end{array}$} & \multirow{2}{*}{$\begin{array}{l}\text { TI } \\
(\%)\end{array}$} \\
\hline & & & & IP & FP & & & & & \\
\hline \multirow[t]{2}{*}{2011} & PM-3 & 12 & 30 & 17.8 & 11.7 & 6.1 & 52.1 & 6.1 & 18.9 & 51.4 \\
\hline & PEHM 2 & 20 & 50 & 15.3 & 11.7 & 3.6 & 30.8 & 3.6 & 21.5 & 58.6 \\
\hline \multirow[t]{2}{*}{2012} & PM 3 & 15 & 36 & 19.9 & 14.1 & 5.0 & 35.5 & 5.0 & 16.8 & 45.8 \\
\hline & PM 5 & 15 & 36 & 20.3 & 14.1 & 6.2 & 43.9 & 6.2 & 16.4 & 44.7 \\
\hline \multirow[t]{4}{*}{2013} & PM 5 & 08 & 20 & 24.5 & 18.9 & 5.6 & 29.6 & 5.6 & 11.7 & 32.3 \\
\hline & PEHM 2 & 10 & 25 & 22.0 & 18.9 & 3.1 & 16.4 & 3.1 & 14.2 & 39.2 \\
\hline & PSM 2 & 06 & 15 & 28.1 & 18.9 & 9.9 & 52.4 & 9.9 & 8.1 & 22.4 \\
\hline & PM 4 & 13 & 32 & 26.8 & 18.9 & 7.9 & 41.8 & 7.9 & 9.4 & 26.0 \\
\hline \multirow{2}{*}{2014} & PM 5 & 09 & 22 & 23.1 & 14.7 & 8.4 & 57.1 & 8.4 & 13.1 & 36.2 \\
\hline & PM 3 & 20 & 50 & 21.1 & 14.7 & 6.4 & 43.5 & 6.4 & 15.1 & 41.7 \\
\hline \multirow[t]{3}{*}{2015} & PM 3 & 07 & 17 & 20.4 & 16.4 & 4.0 & 24.4 & 4.0 & 15.8 & 43.6 \\
\hline & PEHM 2 & 10 & 25 & 22.2 & 16.4 & 5.8 & 35.4 & 5.8 & 14.0 & 38.7 \\
\hline & PM 4 & 05 & 12 & 25.8 & 16.4 & 9.4 & 57.3 & 9.4 & 10.4 & 28.7 \\
\hline \multirow[t]{3}{*}{2016} & PM 3 & 12 & 30 & 25.9 & 20.4 & 5.5 & 26.9 & 5.5 & 10.3 & 28.5 \\
\hline & PEHM 2 & 05 & 12 & 21.0 & 15.4 & 5.6 & 36.4 & 5.6 & 15.2 & 42.0 \\
\hline & PM 4 & 05 & 12 & 24.3 & 15.4 & 9.0 & 58.4 & 9.0 & 11.9 & 32.9 \\
\hline \multirow[t]{3}{*}{2017} & PM 3 & 15 & 36 & 23.6 & 17.7 & 5.9 & 33.3 & 5.9 & 12.6 & 34.8 \\
\hline & PM 4 & 05 & 12 & 29.7 & 17.7 & 12.0 & 67.8 & 12.0 & 6.5 & 18.0 \\
\hline & Average & 192 & 26.2 & 22.9 & 16.2 & 6.6 & 41.3 & 6.6 & 13.4 & 36.9 \\
\hline
\end{tabular}

$\mathrm{IP}=$ Improved practice, $\mathrm{FP}=$ Farmers practice, $\mathrm{EG}=$ Extension gap, $\mathrm{TG}=$ technology gap, $\mathrm{TI}=$ Technology index

Table.5 Cost of cultivation (Rs. ha ${ }^{-1}$ ) net return and benefit cost ratio of maze as affected by improved production technologies over local practices

\begin{tabular}{|c|c|c|c|c|c|c|c|c|c|c|c|}
\hline \multirow[t]{2}{*}{ Year } & \multirow[t]{2}{*}{ Variety } & \multicolumn{2}{|c|}{$\begin{array}{l}\text { Total cost of } \\
\text { cultivation }\end{array}$} & \multicolumn{2}{|c|}{$\begin{array}{l}\text { Gross return } \\
\left(\text { Rs ha }^{-1}\right)\end{array}$} & \multicolumn{2}{|c|}{ Net return (Rs ha-1) } & \multicolumn{2}{|c|}{ B:C ratio } & \multirow{2}{*}{$\begin{array}{l}\text { Add. Cost } \\
\text { of } \\
\text { cultivation }\end{array}$} & \multirow{2}{*}{$\begin{array}{l}\text { Add. Net } \\
\text { returns } \\
\left(\text { Rs.ha }^{-1}\right)\end{array}$} \\
\hline & & IP & FP & IP & FP & IP & FP & IP & FP & & \\
\hline \multirow[t]{2}{*}{2011} & PM-3 & 8550 & 8405 & 23500 & 18900 & 14950 & 10495 & 2.7 & 2.2 & 145 & 4455 \\
\hline & PEHM 2 & 8660 & 8520 & 24800 & 17800 & 16140 & 9395 & 2.9 & 2.0 & 140 & 6745 \\
\hline \multirow[t]{2}{*}{2012} & PM 3 & 8970 & 8850 & 27500 & 20600 & 18530 & 11750 & 3.1 & 2.3 & 120 & 6780 \\
\hline & PM 5 & 8790 & 8650 & 30800 & 21000 & 22010 & 12440 & 3.5 & 2.4 & 140 & 7570 \\
\hline \multirow[t]{4}{*}{2013} & PM 5 & 8890 & 8560 & 32900 & 23000 & 24010 & 14440 & 3.7 & 1.6 & 330 & 9570 \\
\hline & PEHM 2 & 9080 & 8970 & 34500 & 23000 & 25420 & 14030 & 3.8 & 2.5 & 110 & 11390 \\
\hline & PSM 2 & 9700 & 9630 & 36700 & 23000 & 27000 & 13370 & 3.8 & 1.3 & 70 & 13630 \\
\hline & PM 4 & 9690 & 9560 & 30400 & 23000 & 20710 & 13440 & 3.1 & 2.4 & 130 & 7270 \\
\hline \multirow[t]{2}{*}{2014} & PM 5 & 9520 & 9400 & 33200 & 25600 & 23680 & 16200 & 3.5 & 2.5 & 120 & 7480 \\
\hline & PM 3 & 9970 & 9780 & 29600 & 21600 & 19630 & 11820 & 2.9 & 2.2 & 190 & 7810 \\
\hline \multirow[t]{3}{*}{20135} & PM 3 & 9780 & 9650 & 32400 & 21600 & 22620 & 11950 & 3.3 & 2.2 & 130 & 10670 \\
\hline & PEHM 2 & 9650 & 9450 & 35600 & 19800 & 25950 & 10350 & 3.6 & 1.7 & 200 & 15600 \\
\hline & PM 4 & 8180 & 7900 & 39000 & 21700 & 30820 & 13800 & 4.8 & 2.7 & 280 & 17020 \\
\hline \multirow[t]{3}{*}{2016} & PM 3 & 9870 & 9660 & 31600 & 22800 & 21730 & 13140 & 3.2 & 2.3 & 210 & 8590 \\
\hline & PEHM 2 & 10900 & 9870 & 28700 & 20250 & 17800 & 10380 & 2.6 & 2.0 & 1030 & 7420 \\
\hline & PM 4 & 10400 & 9800 & 36500 & 20300 & 26100 & 10500 & 3.4 & 1.9 & 600 & 15600 \\
\hline \multirow[t]{3}{*}{2017} & PM 3 & 12500 & 11050 & 37800 & 25400 & 25300 & 14350 & 3.0 & 1.8 & 1450 & 10950 \\
\hline & PM 4 & 12300 & 11000 & 38900 & 29050 & 26600 & 18050 & 3.2 & 1.5 & 1300 & 8550 \\
\hline & Average & 9744.4 & 9372.5 & 32466.7 & 22133.3 & 22722 & 12772.2 & 3.3 & 2.0 & 371.9 & 9838.9 \\
\hline
\end{tabular}

$\mathrm{IP}=$ Improved practices, $\mathrm{FP}=$ Farmer practices 
These results are in line with the findings of Gurumukhi and Mishra (2003), Sawardekar et al., (2003), Sharma (2003), Hiremath et al., (2007), Hiremath and Nagaraju (2009) and Sreelakshmi et al., (2012). Further, additional cost of Rs. $371.9 \mathrm{ha}^{-1}$ in demonstration has yielded additional net returns of Rs. 9838.9 $\mathrm{ha}^{-1}$ with incremental benefit cost ratio 2.0 suggesting its higher profitability and economic viability of the demonstration. Similar results were also reported by Hiremath and Nagaraju (2009) and Dhaka et al., (2010) in maize crops. The results from the present study clearly brought out the potential of improved production technologies in enhancing maize production and economic gains in rainfed farming situations conditions of this region of Rajasthan. Hence, maize production technologies have broad scope for increasing the area and productivity at each and every level.

\section{Increase in knowledge}

Knowledge level of respondent farmers on various aspects of improved maize production technologies before conducting the frontline demonstration and after implementation was measured and compared by applying paired ' $t$ '-test. It could be seen from the Table 2 that farmers mean knowledge score had increased by 34.1 after implementation of frontline demonstrations. The increase in mean knowledge score of farmers was observed significantly higher. As the computed value of 't-test' (7.98) was statistically significant at 5 $\%$ probability level. The results are at par with Narayanaswamy and Eshwarappa (1998) on pulses crops, Singh and Sharma (2004) on mustard crop, Singh et al., (2007) on different crops like soybean, pigeon pea, black gram and Dhaka et al., (2010) on maize crop. It means there was significant increase in knowledge level of the farmers due to frontline demonstration. This shows positive impact of frontline demonstration on knowledge of the farmers that have resulted in higher adoption of improved farm practices. The results so arrived might be due to the concentrated educational efforts made by the scientists.

\section{Farmer's satisfaction}

The extent of satisfaction level of respondent farmers over extension services and performance of demonstrated variety was measured by Client Satisfaction Index (CSI) and results presented in Table 3. It is observed that majority of the respondent farmers expressed medium $(65.6 \%)$ to the high (20.6\%) level of satisfaction for extension services and performance of technology under demonstrations whereas, very few 14.8 per cent of respondents expressed lower level of satisfaction. The results are in close conformity with the results of Narayanaswamy and Eshwarappa (1998) on pulses crops, Kumaran and Vijayaragavan (2005) on mustard \& gram crops and Dhaka et al., (2010) on maize crop, Dash and Rautaray (2017) and Dash et al., (2018) in green gram crop. The medium to higher level of satisfaction with respect to services rendered, linkage with farmer's and technologies demonstrated etc. indicate stronger conviction, physical and mental involvement in the frontline demonstration which in turn would lead to higher adoption. This shows that the relevance of frontline demonstrations. It indicates that maize grown with low yield are identified by low knowledge, un-favorable attitude towards high yielding varieties, low risk bearers with negative perception of maize production technology. In other wards it may also due to then socio-economic status, lower holdings and unavailability of inputs and credit facilities and to some extent supply and marketing problems. This is a point of concern for research and extension functionaries to disseminate improved maize 
production technologies for raising the productivity of maize at all the levels.

On the basis of the result obtained in present study it can be concluded that the yield gap between conventional practices and improved production technologies was perceptibly higher, there is urgent need to make stronger extension services for educating the cultivators in the implementation of improved production technology. However, the yield level under FLD was better than the local varieties and performance of these varieties could be further improved by adopting recommended production technologies. Hence, it can be observed that increased yield was due to adoption of high yielding varieties and conducting front line demonstration of proven technologies. Yield potentials of crop can be increased to greater extent. This will subsequently increase the income as well as the livelihood of the farming community. From the above research findings it can be also concluded that the maximum number of the respondents had medium level of knowledge and extent of adoption regarding recommended maize production technology. The study reported lack of suitable HYV as major constraint by the beneficiaries and is ranked first followed by low technical knowledge.

\section{References}

Anonymous 2016-17. Rajasthan Agricultural Statistics at a Glance. Directorate of Agriculture, Rajasthan, Jaipur. Pp 5668 .

Anonymous 2017. Vision 2030. Directorate of Maize Research, Pusa, New Delhi (India).

Dash, S.R. and Rautaray, B.K. 2017. Growth parameter and yield of green gram varieties (Vigna radiate L.) in East and South East Costal Plain of Odisha,
India. Int. J. Curr. Microbiol. App. Sci. 6(1):1517-1523.

Dash, S.R., B.K. Rautaray and Dhal, A. 2018. Perception and Constraints faced by Pulse Growers and yield gap analysis of Green Gram (Vigna radiata L.) in East and South East Coastal Plain of Odisha, India. Int. J. Curr. Microbiol. App. Sci. 7(01): 338-346.

Dhaka, B.L., Meena, B.S. and Suwalka, R.L. 2010. Popularization of improved maize production technology through frontline demonstrations in south-eastern Rajasthan. Journal of Agricultural Sciences, 1(1): 39-42.

Dhruw, K.S., Sengar, R.S. and Yadaw, K.N. 2012. Level of knowledge and adoption about recommended maize production technology. Agriculture Update, 7(3\&4):311-315. Gurumukhi, D.R. and Mishra, S. 2003. Sorghum front line demonstration - A success story. Agriculture Extension Review, 15(4):22-23.

Haque, M.S. 2000. Impact of compact block demonstration on increase in productivity of rice. Maharastra Journal of Extension Education, 19(1):22-27.

Hassan, R.M., Onyango, R. and Rutto, J.K. 1998. Relevance of Maize Research in Kenya to Maize Production Problems Perceived by Farmers. In: RM Hassan (Ed.): A GIS Application for Research Planning in Kenya. Oxon: CAB International. Hiremath,

Hiremath, S.M., Nagaraju, M.V. and Shashidhar, K.K. 2007. Impact of front line demonstrations on onion productivity in farmer's field. Paper presented In: National Seminar on Appropriate Extension Strategies for Management of Rural Resources, University of Agricultural Sciences, Dharwad, December 18-20, p.100. 
Joshi, P.K., Singh, N.P., Singh, N.N., Gerpacio, R.V. and Pingali, P.L. 2005. Maize in India: Production Systems, Constraints, and Research Priorities. Mexico, D.F.: CIMMYT.

Kumar, A., Kumar, R., Yadav, V.P.S. and Kumar, R. 2010. Impact assessment of frontline demonstrations of Bajra in Haryana state. Indian Research Journal of Extension Education, 10 (1):105-108.

Kumaran, M, Vijayaragavan, K. 2005. Farmers' satisfaction of agricultural extension services in an irrigation command area. Indian Journal of Extension Education, 41 (3\&4): 8-12.

Mishra, D.K., Paliwal, D.K, Tailor, R.S., Deshwal, A.K. 2009. Impact of frontline demonstrations on yield enhancement of potato. Indian Research Journal of Extension Education, 9(3): 26-28.

Narayanaswamy, C. and Eshwarappa, G. 1998. Impact of front line demonstrations. Indian Journal of Extension Education, 34(1\&2): 14-15.

Nazrul Islam, M., Rezual Karim Md and Safigual Islam Q.M. 2004. Economic performance of BARI Mash 1 (Improved variety of Black gram) with traditional variety at farmers' fields of Bangladesh. Asian Journal of Plant Sciences, 3: 247-250.

Ouma, J.H., De Groote and Gethi, M. 2002. Focused Participatory Rural Appraisal of farmer's perceptions of maize varieties and production constraints in the Moist Transitional Zone in Eastern Kenya. IRMA Socio-Economic Working Paper No. 02-01. Nairobi, Kenya: CIMMYT and KARI.

Ranawat, Y., Ram H., Sisodiya, S.S. and Punjabi, N.K. 2011. Adoption of improved maize cultivation practices by trained and untrained farmers of $\mathrm{KVK}$, Udaipur. Rajasthan Journal of Extension Education, 19:144-147.
S.M. and Nagaraju, M.V. 2009. Evaluation of front line demonstration trials on onion in Haveri district of Karnataka. Karnataka Journal of Agricultural Sciences, 22 (5):1092-1093.

Sain Dass, Singh, K.P. and Yadav, V.K. 2007. Present status and potential of maize hybrids in enhancing the productivity. National Conference on "Doubling Maize Production" organized by IFFCO Foundation, ICAR, DMR, DAC and IFFCL at New Delhi from May 08-09, 2007. p. 13-19.

Samui, S.K., Maitra, S., Roy, D.K., Mondal, A.K. and Saha, D. 2000. Evaluation of front line demonstration on groundnut (Arachis hypogea L.) in Sundarbans. Journal of Indian Society of Coastal Agricultural Research, 18 (2):180-183.

Sawardekar, S.V., Dhane, S.S. and Jadhav, B.B. 2003. Front-line demonstration performance of salt-tolerant rice varieties in coastal saline soils. IRRN, 28 (1):73-74. Sharma, O.P. (2003). Moth bean yield improvement through Front Line Demonstrations. Agriculture Extension Review, 15 (5):11-13.

Singh, D.K., Gautam, U.S. and Singh, R.K. 2007. Study on Yield Gap and Level of Demonstrated Crop Production Technology in Sagar District. Indian Research Journal of Extension Education, 7 (2\&3): 94-95.

Singh, N. and Sharma, F.L. 2004. Impact of front line demonstration on gain in knowledge about mustard production technology among farmers. $2^{\text {nd }}$ National Extension Education Congress, May 22-24, 2004. Society of Extension Education, Agra \& MPUAT, Udaipur: 56.

Sreelakshmi, C.H., Sameer Kumar, C.V. and Shivani, D. 2012. Productivity enhancement of pigeon pea (Cajanus cajan L.) through improved production 
technology, Madras Agricultural Journal, 99 (4-6):248-250.

Tiwari, K.B. and Saxena, A. 2001. Economic Analysis of FLD of oil seeds in Chindwara. Bhartiya Krishi Anusandhan Patrika, 16(3\&4): 185-189.

Tiwari, R.B., Singh, V. and Parihar, P. 2003. Role of front line demonstration in transfer of gram production technology.
Maharashtra Journal of Extension Education, 22 (1): 19.

Tomar, R.K.S., Sahu, B.L., Rupendra, K., Singh and Prajapati, R.K. 2009. Productivity enhancement of black gram (Vigna mungo L.) through improved production technologies in farmers' field. Journal of Food Legumes, 22(3): 202-204.

\section{How to cite this article:}

Meena, M.L. and Aishwarya Dudi. 2018. Growth Parameters and Yield of Maize Varieties (Zea mays L.) in Tribal Hills Area of Pali District, Rajasthan, India. Int.J.Curr.Microbiol.App.Sci. 7(04): 2319-2328. doi: https://doi.org/10.20546/ijcmas.2018.704.266 